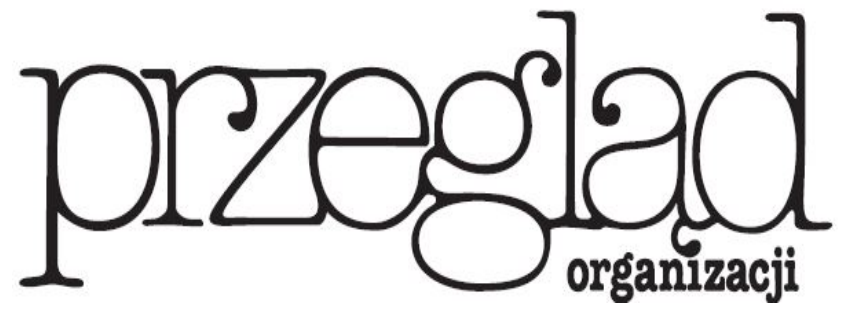

Miesięcznik TNOiK

Założył Karol Adamiecki w 1926 r.

\title{
MOTYWY WSPÓŁPRACY MIĘDZYORGANIZACYJNEJ W DZIALALNOŚCI INNOWACYJNEJ - PERSPEKTYWA PRZEDSIĘBIORSTW PRODUKCYJNYCH W POLSCE
}

https://doi.org/10.33141/po.2019.08.02

\section{Łukasz Wściubiak}

\section{Wprowadzenie}

W spółpraca międzyorganizacyjna odgrywa bardzo istotną rolę we współczesnych procesach innowacyjnych. Ze względu na narastającą zmienność otoczenia, silną presję ze strony konkurentów oraz coraz większą złożoność technologiczną opracowywanych rozwiązań (przy jednoczesnym skracaniu cyklu ich życia) dość powszechnie uważa się, że potencjał działających w pojedynkę przedsiębiorstw jest niewystarczający, aby sprostać stojącym przed nimi wyzwaniom (van de Vrande i in., 2009, s. 436). Wymusza to zmianę dotychczasowej filozofii działania i odejście od orientacji konfliktowo-konfrontacyjnej na rzecz wspólnego dążenia do realizacji założonych celów gospodarczych. Współpraca zaczyna być traktowana jako narzędzie budowania przewagi kon-
Przegląd Organizacji, Nr 8 (955), 2019, ss.12-18 www.przegladorganizacji.pl CTowarzystwo Naukowe Organizacji i Kierownictwa (TNOiK)

kurencyjnej, a w wielu przypadkach jest to jedyna realna droga uzyskania dostępu do niezbędnych zasobów i kompetencji (Marcinkowski, 2018, s. 262-263).

Przedsiębiorstwa mogą nawiązywać proinnowacyjne relacje $\mathrm{z}$ wieloma różnymi typami podmiotów zewnętrznych. W najszerszym ujęciu można zaliczyć do nich: agencje rządowe, instytucje pośredniczące (np. centra transferu technologii), jednostki naukowo-badawcze oraz inne przedsiębiorstwa (Zeng i in., 2010, s. 183-185). Niektórzy autorzy (Tomlinson, Fai, 2013; Chen i in., 2016) w odniesieniu do relacji z innymi przedsiębiorstwami wprowadzają także podział na współpracę w ramach powiązań pionowych ( $\mathrm{z}$ dostawcami i odbiorcami) oraz powiązań poziomych (z konkurentami oraz przedsiębiorstwami z innych sektorów). 
Współpraca $\mathrm{z}$ każdą $\mathrm{z}$ wymienionych grup partnerów ma niewątpliwie nieco inny charakter i znaczenie dla przedsiębiorstwa. Sytuacja ta rodzi także pytanie o przesłanki, jakimi kierują się przedsiębiorstwa przy nawiązywaniu takich relacji. W literaturze przedmiotu kwestia ta pozostaje bowiem głównie w obszarze rozważań teoretycznych. Stosunkowo nieliczne prace o charakterze empirycznym podejmują natomiast problematykę motywów zaangażowania przedsiębiorstw $\mathrm{w}$ relacje $\mathrm{z}$ wybranymi kategoriami podmiotów zewnętrznych, tj. instytucjami naukowo-badawczymi (Veugelers, Cassiman, 2005) bądź też innymi przedsiębiorstwami (Bayona i in., 2001). W dalszym ciągu brakuje natomiast opracowań opartych na analizie porównawczej motywów współpracy z różnymi typami partnerów.

Celem niniejszego artykułu jest rozpoznanie motywów współpracy międzyorganizacyjnej w zakresie działalności innowacyjnej, prowadzonej przez przedsiębiorstwa produkcyjne $\mathrm{z}$ terenu Polski, a także próba identyfikacji różnic $\mathrm{w}$ zakresie motywów zaangażowania badanych przedsiębiorstw w relacje $\mathrm{z}$ instytucjami naukowo-badawczymi oraz podmiotami z sektora biznesu. Podjęto również próbę określenia wpływu wybranych cech przedsiębiorstw (wielkość, poziom innowacyjności, stopień umiędzynarodowienia działalności, rodzinny charakter firmy) na deklarowane motywy współpracy międzyorganizacyjnej.

W artykule wykorzystano wyniki badań przeprowadzonych na celowo dobranej próbie przedsiębiorstw produkcyjnych $\mathrm{z}$ terenu całej Polski, które deklarowały współpracę zarówno z jednostkami naukowymi, jak i podmiotami z sektora przedsiębiorstw. W przeprowadzonych analizach uwzględniono dane pochodzące z 36 podmiotów spełniających powyższe kryteria. Zakres czasowy badań obejmował lata 2014-2016.

\section{Motywy współpracy międzyorganizacyjnej w świetle literatury przedmiotu}

W spółpraca międzyorganizacyjna może stanowić źródło wielu istotnych korzyści. W wymiarze operacyjnym nawiązywanie relacji $\mathrm{z}$ podmiotami zewnętrznymi prowadzi do wzrostu efektywności działania, a w wymiarze strategicznym - do poprawy pozycji konkurencyjnej przedsiębiorstwa (Sudolska, 2011, s. 141-159). Współpraca umożliwia także lepsze wykorzystywanie przez przedsiębiorstwo pojawiających się okazji rynkowych. W literaturze przedmiotu zwraca się jednak uwage na konieczność odpowiedniego ukierunkowania takiej współpracy oraz właściwego doboru partnerów (Nowak, 2010, s. 84-85).

Jedną z podstawowych przesłanek współpracy w zakresie innowacji jest chęć uzyskania dostępu do wiedzy, kompetencji oraz innych komplementarnych zasobów pozostających w dyspozycji partnerów (Yu, Lee, 2017, s. 1453). Ze względu na gwałtownie rosnące koszty prowadzenia prac $\mathrm{B}+\mathrm{R}$ oraz znaczący odsetek projektów kończących się niepowodzeniem, innym ważnym motywem wydaje się także dążenie do podziału pomiędzy współpra- cujących partnerów kosztów i ryzyka prowadzonych prac (Becker, Dietz, 2004, s. 221; Dodgson i in., 2008, s. 148). Narastająca presja ze strony konkurentów oraz skracanie cyklu życia większości produktów wymusza także na przedsiębiorstwach przyspieszenie tempa prac nad nowymi rozwiązaniami, co skutkuje koniecznością coraz szybszego wprowadzania innowacji. Zdaniem wielu autorów (Gorbatyuk i in., 2016), osiągnięcie tego celu jest możliwe właśnie dzięki współpracy z innymi podmiotami.

Konstrukcja wielu programów wspierania innowacyjności, preferująca projekty realizowane wspólnie przez kilku partnerów, może prowadzić do sytuacji, w których motywem nawiązywania relacji $\mathrm{z}$ innymi podmiotami jest chęć pozyskania brakujących środków finansowych $\mathrm{w}$ formie dotacji ze środków publicznych (Klimas, 2015, s. 38-39).

Dzięki intensyfikacji przepływów wiedzy z otoczeniem współpraca międzyorganizacyjna umożliwia ograniczenie niepewności oraz lepszą adaptację do zmian zachodzących w turbulentnym otoczeniu. Warto również podkreślić, że w niektórych przypadkach przedsiębiorstwa angażują się w relacje $\mathrm{z}$ partnerami zewnętrznymi na zasadzie naśladownictwa poczynań konkurencji, która podejmuje działania na rzecz współtworzenia wartości w ramach powiązań sieciowych (Czakon, 2014, s. 84-86).

W literaturze przedmiotu współpraca $z$ innymi podmiotami rozpatrywana jest często jako sposób przezwyciężania barier napotykanych przez przedsiębiorstwo w toku działalności innowacyjnej (Lewandowska, 2013; Kanama, Nishikawa, 2017). Należy jednak podkreślić, że wyniki dotychczasowych badań nie pozwalają na sformułowanie w pełni jednoznacznych wniosków. Niektórzy autorzy (Antonioli i in., 2017) wskazują, że o ile występowanie pojedynczych barier może faktycznie skłaniać przedsiębiorstwa do intensyfikacji współpracy z otoczeniem, to już w przypadku kumulacji kilku różnych barier efekt ten nie występuje.

Jak już wspomniano wcześniej, współpraca przedsiębiorstw $\mathrm{z}$ jednostkami naukowymi może mieć odmienny charakter $\mathrm{w}$ porównaniu do relacji utrzymywanych $\mathrm{z}$ innymi przedsiębiorstwami. Instytucje naukowo-badawcze dysponują bowiem rozbudowaną infrastrukturą badawczą, wyspecjalizowanymi zasobami intelektualnymi, a ich działalność w znacznym stopniu finansowana jest ze środków publicznych (Perkmann, 2015, s. 229-230). Jednostki naukowe nie stanowią także bezpośredniej konkurencji dla swoich partnerów z sektora biznesu, co w znaczący sposób ogranicza niebezpieczeństwo wystąpienia zachowań oportunistycznych (Wściubiak, 2016, s. 116).

W zdecydowanej większości dotychczasowych prac zdaje się dominować obraz współdziałania przedsiębiorstw jako zjawiska pozytywnego i przysparzającego wielu wymiernych korzyści. Należy jednak zauważyć, że korzyści te mogą przybierać różnorodny charakter i mieć odmienną wartość dla poszczególnych podmiotów (Nowak, 2015, s. 49). Tym samym skłonność do współpracy z podmiotami zewnętrznymi (a pośrednio - także motywy nawiązywania takich relacji) może być determinowana przez charakterystykę danego przedsiębiorstwa. 
W literaturze przedmiotu bardzo szeroko dyskutuje się wpływ takich cech, jak: wielkość przedsiębiorstwa, poziom jego innowacyjności i nakładów na $\mathrm{B}+\mathrm{R}$ czy też zaangażowanie w działalność eksportową (Bayona i in., 2001; Dachs i in., 2008). Stosunkowo nowy nurt rozważań dotyczy natomiast oddziaływania na współprace rodzinnego charakteru przedsiębiorstwa. Uważa się bowiem, że ze względu na awersję do ryzyka związanego ze współpracą międzyorganizacyjną oraz dążenie do zachowania niezależności i samodzielności decyzyjnej firmy rodzinne mogą przejawiać mniejszą skłonność do nawiązywania relacji z partnerami zewnętrznymi (Nieto i in., 2015).

\section{Metoda badawcza}

$\mathbf{Z}$ aprezentowane w niniejszym artykule wyniki stanowią fragment szerszego projektu badawczego, adresowanego do przedsiębiorstw reprezentujących relatywnie wysoki poziom innowacyjności, a dotyczącego zagadnień związanych ze współpracą międzyorganizacyjną w działalności innowacyjnej oraz wykorzystaniem instrumentów ochrony własności intelektualnej. Mając świadomość, że podjęta problematyka dotyczy relatywnie niewielkiej grupy przedsiębiorstw, zdecydowano się na zastosowanie celowego doboru próby badawczej. Zaproszenie do udziału w badaniu skierowano do podmiotów wytypowanych na podstawie dostępnych rankingów innowacyjności, wykazów beneficjentów programów współfinansowanych ze środków Unii Europejskiej oraz informacji pochodzących $\mathrm{z}$ baz danych Urzędu Patentowego RP. Stanowiły one grupę przedsiębiorstw produkcyjnych $\mathrm{z}$ terenu całej Polski, które $\mathrm{w}$ subiektywnej ocenie autora posiadały potencjał niezbędny do prowadzenia działalności badawczo-rozwojowej oraz przejawiały zainteresowanie wykorzystywaniem innowacji jako ważnego instrumentu w walce konkurencyjnej. Ostatecznie materiał empiryczny pozyskano od 48 przedsiębiorstw, które wyraziły zgodę na udział w badaniu oraz zwróciły prawidłowo wypełniony kwestionariusz ankietowy. Zakres czasowy badań obejmował lata 2014-2016.

W konstrukcji kwestionariusza ankietowego wyodrębniono kilka bloków pytań, których tematyka dotyczyła m.in. ogólnej charakterystyki przedsiębiorstwa, prowadzonej działalności innowacyjnej i badawczo-rozwojowej, współpracy z podmiotami zewnętrznymi oraz wykorzystywanych instrumentów ochrony własności intelektualnej. W części kwestionariusza poświęconej zagadnieniom współpracy międzyorganizacyjnej znalazły się pytania dotyczące rodzaju i zakresu powiązań przedsiębiorstwa z podmiotami zewnętrznymi oraz motywów i barier nawiązywania tego rodzaju relacji.

$\mathrm{W}$ najbardziej istotnym $-\mathrm{z}$ punktu widzenia niniejszego artykułu - pytaniu, uwzględniono 7 potencjalnych motywów współpracy międzyorganizacyjnej, wytypowanych na podstawie przeprowadzonych studiów literaturowych. Respondenci oceniali ich znaczenie w 5-stopniowej skali Likerta (gdzie: 5 - motyw bardzo ważny, 1 - motyw zupełnie nieistotny). Oceny tej dokonywano osobno w odniesieniu do relacji przedsiębiorstwa $\mathrm{z}$ instytucjami naukowo-badawczymi oraz do relacji z innymi przedsiębiorstwami. Hierar- chię poszczególnych motywów określono na podstawie odsetka badanych przyznających oceny odpowiadające dwóm najwyższym stopniom przyjętej skali (tj. motyw ważny lub bardzo ważny).

Odpowiedzi na powyższe pytania były udzielane wyłącznie przez te przedsiębiorstwa, które $\mathrm{w}$ analizowanym okresie utrzymywały proinnowacyjne relacje z podmiotami zewnętrznymi. Przy opracowywaniu wyników pominięto także odpowiedzi przedsiębiorstw, które współpracowały wyłącznie z jedną spośród uwzględnionych w badaniu kategorii podmiotów (tzn. tylko $\mathrm{z}$ jednostkami naukowymi lub tylko $\mathrm{z}$ innymi przedsiębiorstwami). W konsekwencji spowodowało to zawężenie badanej próby do 36 przedsiębiorstw. Liczba przedsiębiorstw uwzględnionych $\mathrm{w}$ niniejszym badaniu może wydawać się wprawdzie stosunkowo niewielka, należy jednak mieć świadomość, że otwartość na współpracę $\mathrm{z}$ podmiotami zewnętrznymi $\mathrm{w}$ dalszym ciagu nie jest, niestety, zjawiskiem zbyt rozpowszechnionym wśród przedsiębiorstw w Polsce.

Udzielone odpowiedzi przeanalizowano także pod kątem potencjalnego wpływu takich cech badanych przedsiębiorstw, jak: wielkość (liczba zatrudnionych), poziom innowacyjności (innowacje w pełni oryginalne, tj. stanowiące nowość w skali światowej vs. innowacje reprezentujące niższy poziom nowości), intensywność działalności $\mathrm{B}+\mathrm{R}$ (nakłady na $\mathrm{B}+\mathrm{R}$ w relacji do przychodów ze sprzedaży), stopień internacjonalizacji (udział eksportu w przychodach ze sprzedaży) oraz rodzinny charakter firmy.

\section{Wyniki badań}

$\mathbf{Z}$ asadniczą przyczyną, dla której badane przedsiębiorstwa angażowały się we współpracę międzyorganizacyjną, była chęć uzyskania dostępu do niezbędnych zasobów i kompetencji. Blisko połowa respondentów jako ważny motyw wskazywała także potrzebę poszukiwania nowych pomysłów oraz przyspieszenia opracowania i wdrożenia innowacji. $\mathrm{Z}$ kolei dla nieco ponad jednej trzeciej badanych jednym z głównych powodów nawiązywania relacji międzyorganizacyjnych była chęć uzyskania wsparcia w postaci różnego rodzaju dofinansowań ze środków publicznych. Z jednej strony wskazuje to na możliwość stymulowania współpracy międzyorganizacyjnej poprzez odpowiednio zaprojektowane instrumenty finansowe, $\mathrm{z}$ drugiej zaś może rodzić pewne obawy o efektywność wykorzystania wydatkowanych w ten sposób środków.

Uzyskane wyniki wskazują ponadto, że badane przedsiębiorstwa relatywnie rzadko podejmowały współpracę z innymi podmiotami, kierując się chęcią redukcji kosztów i ryzyka prowadzonej działalności innowacyjnej (rys. 1). Być może w znacznym stopniu wynika to ze świadomości wyzwań, związanych $z$ efektywnym zarządzaniem powiązaniami zewnętrznymi przedsiębiorstwa. Relacje te prowadzą bowiem nie tylko do uzyskania szeregu wymiernych korzyści, ale także stanowią potencjalne źródło ryzyka oraz nierzadko wysokich kosztów transakcyjnych.

Przeprowadzone badania wykazały jedynie nieznaczne różnice pomiędzy motywami współpracy $\mathrm{z}$ jednostkami naukowo-badawczymi oraz $\mathrm{z}$ innymi przedsiębiorstwami. 


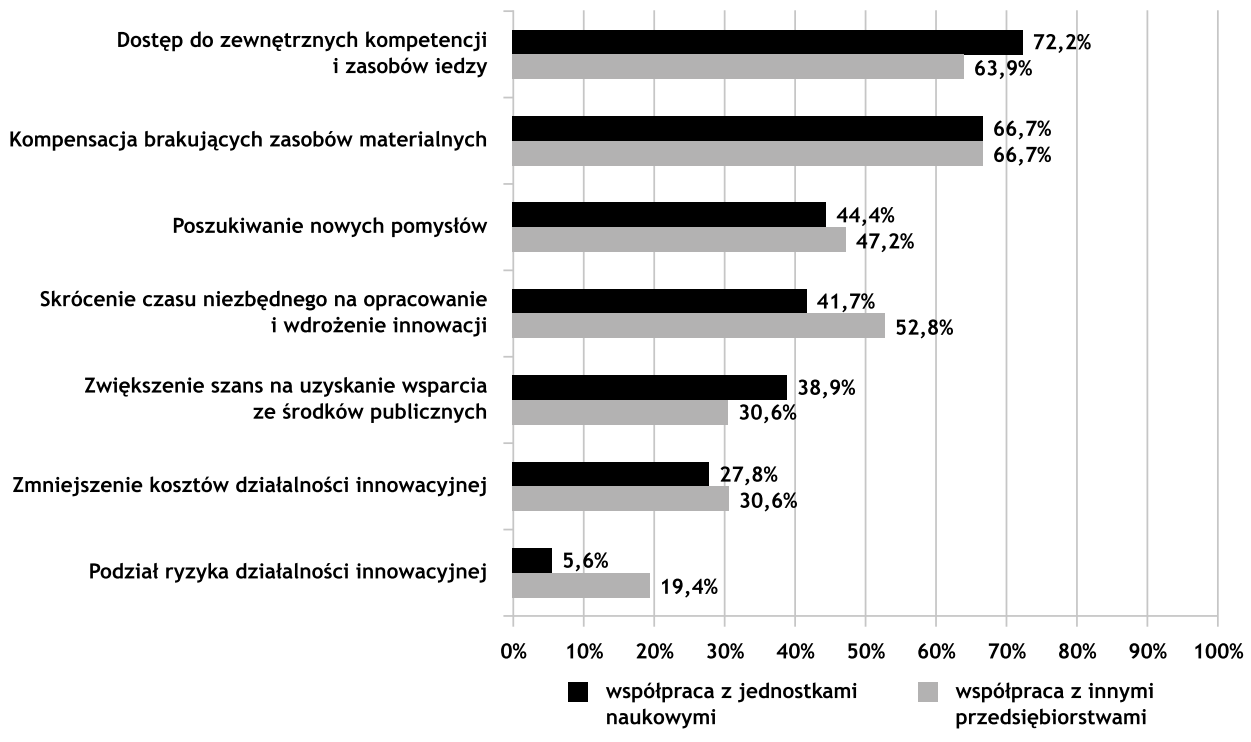

Rys. 1. Motywy współpracy w zakresie działalności innowacyjnej z jednostkami naukowymi oraz innymi przedsiębiorstwami (\%)

Źródło: opracowanie własne

W odniesieniu do relacji utrzymywanych z jednostkami naukowymi nieco większe znaczenie przypisywano dostępowi do wiedzy i kompetencji oraz zwiększeniu szans na uzyskanie wsparcia ze środków publicznych. Z kolei w przypadku współpracy z innymi podmiotami rynkowymi respondenci silniej akcentowali chęć podziału ryzyka oraz skrócenia czasu niezbędnego na opracowanie i wdrożenie innowacji.

Czynnikiem różnicującym znaczenie poszczególnych motywów okazała się natomiast charakterystyka podmiotów objętych niniejszym badaniem. Wpływ wybranych cech badanych przedsiębiorstw na motywy współpracy z podmiotami zewnętrznymi opisano w dalszej części artykułu. Wyniki zestawiono w dwóch tabelach, osobno dla motywów współpracy z jednostkami naukowymi (tab. 1) oraz motywów współpracy z innymi przedsiębiorstwami (tab. 2).

Najsilniejszy wpływ na zróżnicowanie znaczenia poszczególnych motywów współpracy okazała się mieć wielkość przedsiębiorstwa. Podmioty zatrudniające 50 i więcej pracowników przypisywały większą wagę do takich motywów, jak: dostęp do wiedzy i kompetencji, poszukiwanie nowych pomysłów, skrócenie czasu niezbędnego do wprowadzenia innowacji, a także zmniejszenie kosztów i ryzyka prowadzonej działalności innowacyjnej. Z kolei przedsiębiorstwa małe i mikro (0-49 pracowników) zdecydowanie częściej angażowały się we współpracę z myślą o zwiększeniu swoich szans na wsparcie ze środków publicznych oraz uzyskaniu dostępu do zasobów materialnych partnerów.

Innym czynnikiem dość wyraźnie oddziałującym na motywy współpracy badanych przedsiębiorstw $\mathrm{z}$ partnerami zewnętrznymi był także poziom oryginalności wprowadzanych innowacji. Przedsiębiorstwa reprezentujące najwyższy poziom innowacyjności (tj. wprowadzające innowacje stanowiące nowość w skali światowej) silniej akcentowały znaczenie takich motywów, jak: skrócenie czasu opracowania i wdrożenia innowacji, pozyskanie wsparcie ze środków publicznych czy uzyskanie dostępu do zasobów materialnych partnerów. Podmioty wprowadzające innowacje o niższym poziomie oryginalności upatrywały we współpracy szansy na uzyskanie dostępu do wiedzy i kompetencji partnerów oraz znalezienia źródła nowych pomysłów na innowacje.

W odniesieniu do pozostałych czynników, uwzględnionych w niniejszej analizie, trudno już o sformułowanie tak jednoznacznych wniosków. We wszystkich przypadkach można jednak zidentyfikować pewne różnice $\mathrm{w}$ zakresie oceny znaczenia niektórych motywów współpracy.

\section{Dyskusja wyników}

U zyskane wyniki upoważniają do sformułowania wniosku, że przedsiębiorstwa średnie i duże (tj. zatrudniające 50 lub więcej pracowników) wykazują zdolność do bardziej wszechstronnego czerpania korzyści ze współpracy międzyorganizacyjnej. Ich przewaga nad mniejszymi firmami wynika nie tylko $z$ lepszego wyposażenia w zasoby, które mogą być przeznaczane na realizację wspólnych przedsięwzięć, ale także większych umiejętności zarządzania siecią relacji zewnętrznych oraz siły przetargowej, dającej możliwość realnego kształtowania warunków współpracy.

Ze względu na różnice $\mathrm{w}$ zakresie posiadanej bazy intelektualnej oraz przyjętą strategię innowacyjną, przedsiębiorstwa reprezentujące wysoki poziom innowacyjności są zainteresowane nie tyle wykorzystaniem zewnętrznych partnerów jako źródła pomysłów czy gotowych rozwiązań (co można zaobserwować w przypadku firm wdrażających rozwiązania o niższym poziomie oryginalności), lecz raczej zaangażowaniem ich w prace nad już realizowanymi projektami, w celu jak najszybszego doprowadzenia ich do pomyślnego finału.

W porównaniu do pozostałych przedsiębiorstw, podmioty prowadzące działalność o silnym stopniu umiędzynarodowienia zdają się przykładać wyraźnie większą wagę do relacji $\mathrm{z}$ innymi podmiotami rynkowymi. 
Tabela 1. Wpływ charakterystyki badanych przedsiębiorstw na motywy współpracy z jednostkami naukowymi (\%)

\begin{tabular}{|c|c|c|c|c|c|c|c|c|}
\hline $\begin{array}{l}\text { Charakterystyka } \\
\text { przedsiębiorstwa }\end{array}$ & 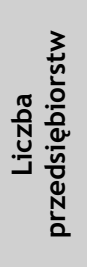 & 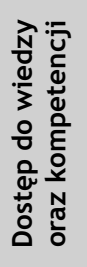 & 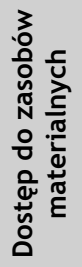 & 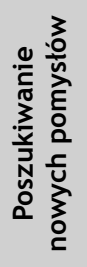 & 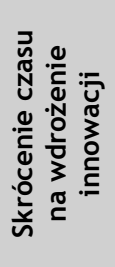 & 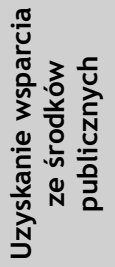 & 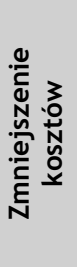 & 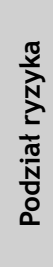 \\
\hline 0-49 pracowników & 17 & 64,7 & 70,6 & 35,3 & 35,3 & 58,8 & 17,6 & 5,9 \\
\hline 50 i więcej pracowników & 19 & 78,9 & 63,2 & 52,6 & 47,4 & 21,1 & 36,8 & 5,3 \\
\hline innowacje naśladowcze & 18 & 83,3 & 61,1 & 61,1 & 38,9 & 33,3 & 27,8 & 5,6 \\
\hline innowacje oryginalne & 18 & 61,1 & 72,2 & 27,8 & 44,4 & 44,4 & 27,8 & 5,6 \\
\hline nakłady na $\mathrm{B}+\mathrm{R}$ poniżej $4 \%$ & 21 & 76,2 & 66,7 & 47,6 & 47,6 & 38,1 & 28,6 & 4,8 \\
\hline nakłady na B+R powyżej $4 \%$ & 15 & 66,7 & 66,7 & 40,0 & 33,3 & 40,0 & 26,7 & 6,7 \\
\hline $\begin{array}{l}\text { udział eksportu w przychodach } \\
\text { ze sprzedaży do } 20 \%\end{array}$ & 16 & 75,0 & 68,8 & 37,5 & 43,8 & 43,8 & 18,8 & 12,5 \\
\hline $\begin{array}{l}\text { udział eksportu w przychodach } \\
\text { ze sprzedaży powyżej } 20 \%\end{array}$ & 20 & 70,0 & 65,0 & 50,0 & 40,0 & 35,0 & 35,0 & 0,0 \\
\hline firma rodzinna & 20 & 75,0 & 55,0 & 30,0 & 45,0 & 55,0 & 25,0 & 5,0 \\
\hline firma nierodzinna & 16 & 68,8 & 81,3 & 62,5 & 37,5 & 18,8 & 31,3 & 6,3 \\
\hline
\end{tabular}

Źródto: opracowanie własne

Tabela 2. Wpływ charakterystyki badanych przedsiębiorstw na motywy wspótpracy z innymi przedsiębiorstwami (\%)

\begin{tabular}{|c|c|c|c|c|c|c|c|c|}
\hline $\begin{array}{l}\text { Charakterystyka } \\
\text { przedsiębiorstwa }\end{array}$ & 芯 & 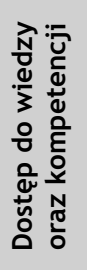 & 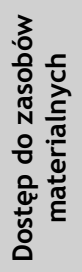 & 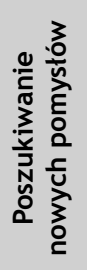 & 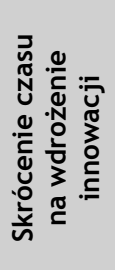 & 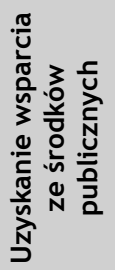 & 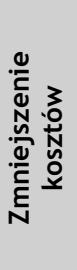 & $\frac{\substack{\frac{0}{\lambda} \\
\frac{N}{2}}}{\frac{\pi}{N}}$ \\
\hline 0-49 pracowników & 17 & 58,8 & 76,5 & 41,2 & 47,1 & 41,2 & 17,6 & 11,8 \\
\hline 50 i więcej pracowników & 19 & 68,4 & 57,9 & 52,6 & 57,9 & 21,1 & 42,1 & 26,3 \\
\hline innowacje naśladowcze & 18 & 72,2 & 55,6 & 50,0 & 38,9 & 16,7 & 27,8 & 27,8 \\
\hline innowacje oryginalne & 18 & 55,6 & 77,8 & 44,4 & 66,7 & 44,4 & 33,3 & 11,1 \\
\hline nakłady na $B+R$ poniżej $4 \%$ & 21 & 76,2 & 71,4 & 61,9 & 52,4 & 28,6 & 33,3 & 14,3 \\
\hline nakłady na $B+R$ powyżej $4 \%$ & 15 & 46,7 & 60,0 & 26,7 & 53,3 & 33,3 & 26,7 & 26,7 \\
\hline $\begin{array}{l}\text { udział eksportu w przychodach } \\
\text { ze sprzedaży do } 20 \%\end{array}$ & 16 & 56,3 & 56,3 & 43,8 & 43,8 & 31,3 & 37,5 & 18,8 \\
\hline $\begin{array}{l}\text { udział eksportu w przychodach } \\
\text { ze sprzedaży powyżej } 20 \%\end{array}$ & 20 & 70,0 & 75,0 & 50,0 & 60,0 & 30,0 & 25,0 & 20,0 \\
\hline firma rodzinna & 20 & 75,0 & 70,0 & 50,0 & 50,0 & 35,0 & 30,0 & 15,0 \\
\hline firma nierodzinna & 16 & 50,0 & 62,5 & 43,8 & 56,3 & 25,0 & 31,3 & 25,0 \\
\hline
\end{tabular}

Źródło: opracowanie własne

Być może wynika to $\mathrm{z}$ faktu, że dla pomyślnego przebiegu przedsięwzięć innowacyjnych prowadzonych przez tę grupę badanych duże znaczenie ma wiedza praktyczna, dotycząca chociażby bieżących uwarunkowań rynkowych. Silna presja ze strony konkurentów, doświadczana na rynkach międzynarodowych, może także wymuszać większą szybkość działania, szczególnie w obszarze działalności innowacyjnej.
Można odnieść wrażenie, że przedsiębiorstwa rodzinne nie dostrzegają w pełni potencjału, jaki jest związany ze współpracą $z$ jednostkami naukowymi. Być może w znacznej mierze wynika to ze specyficznych uwarunkowań kulturowych firm rodzinnych, które zdają się nie przystawać do mocno sformalizowanych i zbiurokratyzowanych realiów, w jakich funkcjonują instytucje naukowo-badawcze. 


\section{Podsumowanie}

W obliczu zmian zachodzących w otoczeniu społeczno-gospodarczym przedsiębiorstwa pragnące wykorzystywać innowacje jako skuteczny instrument $\mathrm{w}$ walce konkurencyjnej coraz częściej stają wobec konieczności nawiązywania współpracy z innymi podmiotami rynkowymi, uczelniami wyższymi oraz instytutami naukowo-badawczymi. Rozpoznanie motywów, jakimi kierują się innowacyjne przedsiębiorstwa przy nawiązywaniu tego typu relacji, jest nieodzowne dla prawidłowego zrozumienia charakteru współpracy międzyorganizacyjnej oraz związanych $\mathrm{z}$ nią wyzwań. Wiedza ta może być cenna nie tylko dla badaczy zainteresowanych analizowaną problematyką, ale także dla praktyków biznesu oraz decydentów odpowiedzialnych za kształtowanie polityki innowacyjnej.

Zaprezentowane $\mathrm{w}$ niniejszym artykule wyniki badań, przeprowadzonych na dobranej w sposób celowy próbie przedsiębiorstw produkcyjnych $\mathrm{z}$ terenu całej Polski, pozwalają stwierdzić, że większość spośród przebadanych podmiotów postrzega współpracę z partnerami zewnętrznymi głównie przez pryzmat możliwości kompensowania brakujących zasobów i kompetencji. Wydaje się jednak, że w przypadku przynajmniej części przedsiębiorstw można mówić o bardziej złożonych przyczynach zaangażowania $\mathrm{w}$ relacje międzyorganizacyjne. Świadczy o tym relatywnie wysokie znaczenie takich motywów, jak: poszukiwanie nowych pomysłów, dążenie do skrócenia czasu potrzebnego na wdrożenie innowacji czy też zwiększenie szans na uzyskanie wsparcia ze środków publicznych.

$\mathrm{W}$ toku przeprowadzonych analiz nie stwierdzono zasadniczych różnic w zakresie motywów współpracy badanych przedsiębiorstw z jednostkami naukowo-badawczymi oraz innymi podmiotami z sektora biznesu. Być może więc odmienny charakter powiązań utrzymywanych z poszczególnymi typami partnerów zewnętrznych przekłada się nie tyle na motywy ich nawiązywania, lecz na rodzaj zasobów i kompetencji pozyskiwanych za pośrednictwem takich relacji. Kwestia ta wymaga jednak dalszych, pogłębionych badań.

Czynnikami najsilniej różnicującymi znaczenie poszczególnych motywów współpracy okazały się natomiast: wielkość przedsiębiorstwa oraz poziom jego innowacyjności. Wydaje się, że przyczyn takiego stanu rzeczy należy upatrywać zarówno w odmiennych potrzebach oraz oczekiwaniach poszczególnych grup przedsiębiorstw, jak i w występujących różnicach w zakresie pozostających w ich dyspozycji zasobów. Fakt ten powinien zostać uwzględniony przy projektowaniu instrumentów wsparcia, mających na celu stymulowanie rozwoju powiązań międzyorganizacyjnych przedsiębiorstw w Polsce.

Zaprezentowane wyniki badań nie są wolne od pewnych ograniczeń, wynikających przede wszystkim ze stosunkowo niewielkich rozmiarów próby badawczej oraz jej nielosowego doboru. Rezultaty te nie powinny być zatem w bezkrytyczny sposób uogólniane, ale stanowić raczej asumpt do dalszych dyskusji oraz badań empirycznych. Niezwykle interesującym kierunkiem dalszych działań wydaje się chociażby podjęcie wysiłków na rzecz lepszego zrozumienia charakteru i znaczenia współpracy międzyorganizacyjnej z poszczególnymi kategoriami partnerów na różnych etapach realizacji innowacyjnych przedsięwzięć.

\section{dr inż. Łukasz Wściubiak \\ Uniwersytet Ekonomiczny w Poznaniu \\ Wydział Zarządzania \\ ORCID: 0000-0003-3576-2323 \\ e-mail: lukasz.wsciubiak@ue.poznan.pl \\ Bibliografia}

[1] Antonioli D., Marzucchi A., Savona M. (2017), Pain Shared, Pain Halved? Cooperation as a Coping Strategy for Innovation Barriers, „The Journal of Technology Transfer”, Vol. 42, No. 4, pp. 841-864.

[2] Bayona C., Garcia-Marco T., Huerta E. (2001), Firms' Motivations for Cooperative R\&D: An Empirical Analysis of Spanish Firms, „Research Policy”, Vol. 30, No. 8, pp. 1289-1307.

[3] Becker W., Dietz J. (2004), R\&D Cooperation and Innovation Activities of Firms. Evidence for the German Manufacturing Industry, ,Research Policy”, Vol. 33, No. 2, pp. 209-223.

[4] Chen Y., Vanhaverbeke W., Du J. (2016), The Interaction between Internal $R \& D$ and Different Types of External Knowledge Sourcing: An Empirical Study of Chinese Innovative Firms, „R\&D Management”, Vol. 46, No. S3, pp. 1006-1023.

[5] Czakon W. (2014), Koopetycja $w$ rozwoju przedsiębiorstw high-tech, [w:] A. Zakrzewska-Bielawska (red.), Koopetycja w rozwoju przedsiębiorstw high-tech. Determinanty i dynamika, Agencja Wydawnicza Placet, Warszawa, s. 65-91.

[6] Dachs B., Ebersberger B., Pyka A. (2008), Why do Firms Co-operate for Innovation? A Comparision of Austrian and Finnish CIS 3 Results, „International Journal of Foresight and Innovation Policy", Vol. 4, No. 3-4, pp. 200-229.

[7] Dodgson M., Gann D., Salter A. (2008), The Management of Technological Innovation. Strategy and Practice, Oxford University Press, Oxford-New York.

[8] Gorbatyuk A., van Overwalle G., van Zimmeren E. (2016), Intellectual Property Ownership in Coupled Open Innovation Processes, „IIC - International Review of Intellectual Property and Competition Law", Vol. 47, No. 3, pp. 262-302.

[9] Kanama D., Nishikawa K. (2017), What Type of Obstacles in Innovation Activities Make Firms Access University Knowledge? An Empirical Study of the Use of University Knowledge on Innovation Outcomes, „The Journal of Technology Transfer”, Vol. 42, No. 1, pp. 141-157.

[10] Klimas P. (2015), Przestanki i bariery zawiazywania więzi międzyorganizacyjnych, „Problemy Zarządzania”, Nr 1, s. 29-46.

[11] Lewandowska M.S. (2013), Bariery innowacji a kooperacja przedsiębiorstw. Efekt supresji, „Przegląd Organizacji”, Nr 4, s. $20-26$

[12] Marcinkowski B. (2018). Ryzyko kooperacji międzyorganizacyjnej - perspektywa malych przedsiębiorstw, „Przedsiębiorczość i Zarządzanie", Nr 7, cz. II, s. 261-273.

[13] Nieto M.J., Santamaria L., Fernandez Z. (2015), Understanding the Innovation Behavior of Family Firms, ,Journal of Small Business Management”, Vol. 53, No. 2, pp. 382-399.

[14] Nowak D. (2010), Innowacyjność przedsiębiorstw w kooperacji przemysłowej, Zeszyty Naukowe Uniwersytetu Ekonomicznego w Poznaniu, Nr 131, s. 81-96. 
[15] Nowak D. (2015), Bariery rozwoju relacji kooperacyjnych, „Problemy Zarządzania”, Nr 1, s. 47-67.

[16] Perkmann M. (2015), University-Industry Relations, [in:] D. Audretsch, C. Hayter, A. Link (eds.), Concise Guide to Entrepreneurship, Technology and Innovation, Edward Elgar, Cheltenham-Northampton, pp. 227-233.

[17] Sudolska A. (2011), Uwarunkowania budowania relacji proinnowacyjnych przez przedsiębiorstwa $w$ Polsce, Wydawnictwo Naukowe UMK, Toruń.

[18] Tomlinson P., Fai F. (2013), The Nature of SME Co-operation and Innovation: A Multi-scalar and Multi-dimensional Analysis, „International Journal of Production Economics”, Vol. 141, No. 1, pp. 316-326.

[19] van de Vrande V., de Jong J., Vanhaverbeke W., de Rochemont M. (2009), Open Innovation in SMEs: Trends, Motives and Management Challenges, „Technovation”, Vol. 29, No. 6-7, pp. 423-437.

[20] Veugelers R., Cassiman B. (2005), R\&D Cooperation between Firms and Universities. Some Empirical Evidence from Belgian Manufacturing, „International Journal of Industrial Organization", Vol. 23, No. 5-6, pp. 355-379.

[21] Wściubiak Ł. (2016), Formy wspótpracy małych i średnich przedsiębiorstw wysokich technologii w Polsce ze środowiskiem naukowym: wplyw charakterystyki przedsiębiorstwa oraz jego działalności, „Studia Oeconomica Posnaniensia”, Nr 2, s. 113-135.

[22] Yu G.J., Lee J. (2017), When Should a Firm Collaborate with Research Organizations for Innovation Performance? The Moderating Role of Innovation Orientation, Size, and Age, „The Journal of Technology Transfer”, Vol. 42, No. 6, pp. 1451-1465.
[23] Zeng S.X., Xie X.M., Tam C.M. (2010), Relationship between Cooperation Networks and Innovation Performance of SMEs, „Technovation”, Vol. 30, No. 3, pp. 181-194.

\section{Motives of Inter-organisational Cooperation in Innovation Activity - A View from the Perspective of Manufacturing Enterprises in Poland}

\section{Summary}

The aim of this paper is to identify the motives of innovation-related inter-organisational cooperation undertaken by manufacturing enterprises in Poland. The study compares the motives of cooperation with research institutions as well as with entities from the enterprise sector. The impact of selected features of the surveyed enterprises on the declared motives of cooperation has also been examined. The presented analyses are based on the results of a survey carried out among a purposively selected sample of manufacturing enterprises from Poland. The time range of the research covered the period 2014-2016. The main reason why the surveyed companies were involved in the external relations was to gain access to the resources and competences of their partners. The size of the enterprise and the level of its innovativeness were the two key factors that diversified the importance of particular motives of cooperation.

\section{Keywords}

innovation, inter-organizational cooperation, manufacturing enterprises 